\title{
Intensive Care Unit-Acquired Infections and Association of These Infections with Mortality: A Prospective Study in a Turkish Tertiary Care Hospital
}

\author{
Bircan Kayaaslan ${ }^{1}$, Ayse But ${ }^{2}$, Aliye Bastug ${ }^{2}$, Ahmet Sercelik², Halide Aslaner², Meltem Arzu Yetkin², Esragul \\ Akinci2 ${ }^{2}$ Hurrem Bodur ${ }^{2}$ \\ ${ }^{1}$ Infectious Diseases and Clinical Microbiology Department/ Yildırım Beyazıt University, Faculty of Medicine, Ankara Atatürk \\ Education and Research Hospital, Ankara \\ ${ }^{2}$ Infectious Diseases and Clinical Microbiology Department/Ankara Numune Education and Research Hospital, Ankara
}

\begin{abstract}
Objective: This study aimed to investigate epidemiological characteristics of infections and risk factors for mortality in intensive care unit (ICU) patients.

Methods: A total of 164 patients hospitalized at Ankara Numune Education and Research Hospital in the medical and surgical ICU over 48 hours were included in the study over a period of nine months. The patients were followed prospectively until they died or were discharged from the ICU. Demographic characteristics of patients, underlying diseases, history of surgical operations, Acute Physiology and Chronic Health Evaluation II (APACHE II) score at admission, usage of invasive devices, nosocomial infections, isolated microorganisms, and outcome of cases were recorded on the standardized patient forms.

Results: Of the patients, $96.3 \%$ (158) had at least one underlying disease, with neurological disorders being the most frequent. The mean length of stay in the ICU was $20.3 \pm 18.7$ days, while the APACHE II score at admission was $16.8 \pm$ 7.3. During follow-up, 105 infection episodes occurred in 65 patients. Pneumonia (41.0\%) was the most frequent infection. Acinetobacter baumannii was the most frequently isolated organism, and the most effective antimicrobials against these strains were colistin (97.3\%) and tigecycline (83.0\%). Rude mortality rate was estimated at 30.5\% (50 patients). In multivariate logistic regression analysis, the APACHE II score was $\geq 15$ at admission, surgical site infection acquired in the ICU and infection caused by $A$. baumannii were found to be independent risk factors for mortality $(p 0.039,0.040$ and 0.025 , respectively).
\end{abstract}

Conclusion: Infections acquired in the ICU, especially those caused by A. baumannii, increase the mortality rate. Because $A$. baumannii is resistant to most antibiotics, treatment becomes very difficult. Early empirical treatment against A. baumannii may decrease the mortality rate in ICUs. J Microbiol Infect Dis 2016;6(2): 53-59

Key words: Nosocomial infections, intensive care unit, mortality risk factors, A. baumannii

\section{Yoğun Bakım Ünitesinde Gelişen Enfeksiyonlar ve Mortalite ile ilişsisi: Prospektif Üçüncü Basamak Bir Türk Hastanesindeki Çalışma}

\section{ÖZET}

Amaç: Biz bu çalışmada, yoğun bakım ünitesinde (YBÜ) gelişen enfeksiyonların epidemiyolojik özelliklerini ve mortalite ile ilişkili risk faktörlerini araştırmayı hedefledik.

Yöntemler: Dokuz aylık bir periyotta Ankara Numune Eğitim ve Araştırma Hastanesi medikal ve cerrahi YBÜ'de 48 saatten uzun süre yatan toplam 164 hasta çalışmaya dahil edildi. Hastalar ölene ya da YBÜ'den taburcu olana kadar prospektif olarak izlendi. Hastaların demografik özellikleri, altta yatan hastalıkları, geçirilmiş cerrahi operasyon öyküsü, yatıştaki Akut Fizyoloji ve Kronik Sağlık Değerlendirilmesi II (APACHE II) skoru, invaziv alet kullanımı, YBÜ'de yatarken gelişen enfeksiyonlar, izole edilen mikroorganizmalar ve hastaların akıbeti özel hasta formalarına kaydedildi.

Bulgular: En sık nörolojik hastalık olmak üzere hastaların 158'inin $(\% 96,3)$ en az bir altta yatan hastalığı mevcuttu. Ortalama YBÜ yatış süresi 20,3 \pm 18,7 gün ve ortalama APACHE II skoru 16,8 \pm 7,3 idi. İzlemde 65 hastada toplam 105

Correspondence: Bircan Kayaaslan,

Yıldırım Beyazıt University, Faculty of Medicine,Ankara Atatürk Education and Research Hospital, Infectious Diseases and Clini-cal Microbiology Department Email: drbican@gmail.com Received: 21.09.2015, Accepted: 19.02.2016 Copyright (C) Journal of Microbiology and Infectious Diseases 2016, All rights reserved 
enfeksiyon epizodu gelişti. En sık tespit edilen enfeksiyon pnömoni idi. En sık izole edilen enfeksiyon etkeni ise Acinetobacter baumannii ve bu mikroorganizmaya en etkili bulunan antibiyotikler kolistin $(\% 97,3)$ ve tigesiklin $(\% 83,0)$ idi. Kaba mortalite hızı \% 30,5 olarak saptandı. Multivariate lojistik regresyon analizinde, yatıştaki APACHE II skorunun $\geq 15$ olması, YBÜ'de yatarken cerrahi alan enfeksiyonu gelişmesi ve etken olarak hastadan A. baumannii izole edilmesi mortalite için bağımsız risk faktörü olarak saptandı ( $0,039,0,040$ ve 0,025 , sırasıyla).

Sonuç: YBÜ yatışı sırasında gelişen enfeksiyonlar, özellikle etken A.baumannii ise mortaliteyi artırmaktadır. Birçok antibiyotiğe dirençli olması nedeni ile bu mikroorganizmanın tedavisi oldukça güçtür. A. baumannii'ye etkili erken ampirik tedavi YBÜ'de hayat kurtarıcı olabilir ve mortalite oranlarını düşürebilir.

Anahtar kelimeler: Nozokomiyal enfeksiyonlar, yoğun bakım ünitesi, mortalite risk faktörleri, A.baumannii

\section{INTRODUCTION}

Nosocomial infection ( $\mathrm{NI})$ is one of the most important complications associated with hospitalization and causes an increase in mortality, morbidity, and treatment costs [1]. In particular, patients admitted to the ICU have an increased risk of developing hospital infections because of reduced host defenses, frequent use of invasive devices, and administration of drugs that predispose for infections [2-5]. Moreover, the pathogens isolated in ICU infections have higher resistance rates to commonly used antimicrobial agents compared to those in community and hospital ward infections [3].

Numerous risk factors affect mortality in the ICU. In previous studies, advanced age, diagnosis at admission, invasive procedures, and length of stay in the ICU were reported risk factors for mortality [6-8]. The association between infections and mortality was emphasized in many large series studies $[1,9]$.

The first aim of this study was to determine the incidence of NIs and the etiological agents isolated in these infections. The second aim was to investigate risk factors for mortality.

\section{METHODS}

This study was carried out at a tertiary care hospital, Ankara Numune Education and Research Hospital, between April and December 2013. Both surgical and medical cases hospitalized in a 30-bed ICU over 48 hours were included in the study. The patients who were pregnant, younger than 18 years old, transferred from another ICU, or staying less than 48 hours in the ICU were excluded.

The patients were followed prospectively until they died or were discharged from the ICU. In addition to demographic characteristics of the patients, the standardized patient forms included the following information: dates of admission to the ICU and discharge from the ICU; primary reason for ICU ad- mission; underlying diseases; history of surgical operation; usage of invasive devices and their duration for endotracheal intubation; urinary catheterization; nasogastric tube and central venous catheterization; $\mathrm{NI}$ at admission or acquired in ICU; culture results; antimicrobial treatment; and outcomes of cases. The APACHE II scores on the first day in the ICU were used to assess the severity of illness. Hematological and biochemical tests were performed every day. Deep tracheal aspirate and urine samples were cultured on admission and weekly afterward for surveillance. Chest plain radiography was performed weekly or in suspicion of pneumonia. Computed tomography was taken when chest radiography was inadequate for the diagnosis. Blood cultures and/ or intravascular catheter tips cultures were taken in suspicion of blood stream infection. In clinical suspicion of infection, deep tracheal aspirate, urine, or samples from other infection sites (wound, decubitus ulcers, or cerebrospinal fluid) were taken for culture. The infectious disease specialist visited the patients daily and collected data about clinical findings and development of infections, and if necessary ordered antimicrobial treatment. NIs were diagnosed according to the criteria of the Centers for Disease Control and Prevention, which are based on clinical and laboratory findings [10]. Infection at the time of admission was only accepted as a nosocomial infection when a new infection developed with a different microorganism or in another anatomical site during the ICU stay. Isolated bacteria were identified by conventional methods and tested for antibiotic susceptibility by the Kirby-Bauer disc diffusion technique according to Clinical and Laboratory Standards Institute (CLSI) specifications [11] The BacT/ALERT® 3D Microbial Detection System (bioMerieux/France) was used for blood culture.

Patients were grouped as "died" and "survived" cases, and the groups were compared according to the following factors: age; gender; primary diagnosis at admission to the ICU; underlying diseases; length of ICU stay; development of the infections; 
site of the infections; isolated microorganisms; presence of $A$. baumannii in clinical samples; applied invasive procedures (central venous catheter, tracheotomy and/or intubation, mechanical ventilation); and APACHE II score at admission. All probable risk factors that may be associated with mortality were included in the analysis. APACHE II scores were grouped as lower $(<15)$ and higher $(\geq 15)$. Deaths that occurred in the ICU and deaths that occurred within 48 hours of discharge or transport from the ICU were accepted as ICU related mortality.

\section{Statistical Analysis}

Statistical analyses were performed with Statistical Package for Social Sciences (SPSS) software, version 16.0. Chi-square, Mann-Whitney $U$, and logistic regression analysis tests were used. All $p$ values $<0.05$ were considered significant.

\section{RESULTS}

A total of 164 patients were included in the study during a period of nine months, and $83(50.4 \%)$ were male. The mean age was $66.6 \pm 17.4$ years, and $96.3 \%$ had at least one underlying disease, with neurological disorders (51.8\%) being the most frequent. Of the patients, $15.2 \%$ had an operation one week before admission to the ICU, $13.4 \%$ had trauma history, and $29.9 \%$ had an infection at the time of admission to the ICU. The other demographic and clinical data of the patients is shown in Table 1.

Table 1. Demographic and epidemiological characteristics of the patients

\begin{tabular}{lc}
\hline Sex, male, $\mathrm{n}(\%)$ & $83(50.4)$ \\
\hline Age, years (mean) & $66.6 \pm 17.4$ \\
\hline Average APACHE II score & $16.8 \pm 7.3$ \\
\hline Average length of ICU-stay, days & $20.3 \pm 18.7$ \\
\hline Underlying diseases, at least one, $\mathrm{n}(\%)$ & $158(96.3)$ \\
\hline Neurological disorders, $\mathrm{n}(\%)$ & $85(51.8)$ \\
\hline Hypertension, $\mathrm{n}(\%)$ & $69(42.1)$ \\
\hline Cardiovascular diseases, $\mathrm{n}(\%)$ & $45(27.4)$ \\
\hline Pulmonary diseases, $\mathrm{n}(\%)$ & $38(23.2)$ \\
\hline Diabetes mellitus, $\mathrm{n}(\%)$ & $37(22.6)$ \\
\hline Malignity, $\mathrm{n}(\%)$ & $29(17.7)$ \\
\hline Renal diseases, $\mathrm{n}(\%)$ & $26(15.8)$ \\
Operation (1 week before and & $25(15.2)$ \\
during ICU stay), $\mathrm{n}(\%)$ & $22(13.4)$ \\
Trauma, $\mathrm{n}(\%)$ & $49(29.9)$ \\
\hline Infection at the admission to ICU
\end{tabular}

During follow-up, 105 infection episodes occurred in 65 patients (39\%). The incidence rate of $\mathrm{NI}$ was 64 infections per 100 patient admissions and 34.3 infections per 1000 patient days. Pneumonia $(41 \%)$ was the most frequent infection, followed by urinary tract infection (26\%) and catheter-related bacteremia $(19 \%)$. The causative agents were detected in $46.0 \%$ of the infections. A. baumannii was the most frequently isolated pathogen (Table 2). The most active antimicrobials against $A$. baumannii were colistin (97.3\%) and tigecycline (83\%). Carbapenem and piperacillin-tazobactam resistance rates among $\mathrm{A}$. baumannii were $100 \%$, while cefoperazone-sulbactam resistance rate was $80 \%$.

Table 2. Etiological agents in infections acquired in ICU

\begin{tabular}{lcc}
\hline & $\mathbf{n}$ & $\mathbf{\%}$ \\
\hline Acinetobacter baumannii & 15 & 26.8 \\
Enterococcus spp & 9 & 16.1 \\
S. aureus & 8 & 14.3 \\
E. coli & 7 & 12.5 \\
P. aeruginosa & 6 & 10.7 \\
Serratia spp & 5 & 8.9 \\
Candida & 3 & 5.3 \\
Klebsiella spp & 2 & 3.6 \\
Morganella morganni & 1 & 1.8 \\
Total & $\mathbf{5 6}$ & $\mathbf{1 0 0}$ \\
\hline
\end{tabular}

The crude mortality rate was $30.5 \%$ (50 patients). In a comparison of "died" and "survived" patients, there were no significant differences in terms of age, sex, and length of ICU stay. Underlying neurological diseases, infections acquired during ICU stay (especially surgical site infection and pneumonia), invasive device usage, isolation of $A$. baumannii from the patient samples, and APACHE II score $\geq 15$ at admission were found as statistically significant risk factors for mortality in univariate analysis ( $P<0.005$ for each) (Table 3$)$. Multivariate logistic regression analysis showed that APACHE II score $\geq 15$ at admission, surgical site infection acquired in the ICU, and isolation of $A$. baumannii were independent risk factors for mortality $(P$ $=0.039,0.040$ and 0.025, respectively) (Table 4). The length of stay in the ICU was longer in patients with $A$. baumannii infection than in cases without $A$. baumannii infection $(32.9 \pm 20.5$ vs. $19.9 \pm 17.3$ days, respectively, $p=0.005$ ). 
Table 3. Mortality risk factors, univariate analyses

\begin{tabular}{|c|c|c|c|}
\hline Risk factor & $\begin{array}{c}\text { Patients died } \\
n,(\%)(n=50)\end{array}$ & $\begin{array}{c}\text { Patients survived } \\
n,(\%)(n=114)\end{array}$ & p value \\
\hline Age, years (mean) & $68.2 \pm 15.9$ & $65.9 \pm 18.1$ & 0.382 \\
\hline Sex, male, n (\%) & $25(50)$ & $58(50.9)$ & 0.918 \\
\hline Average length of ICU-stay & $21.36 \pm 21.2$ & $17.57 \pm 20.3$ & 0.178 \\
\hline Underlining disease (at least one), n (\%) & $49(98)$ & $109(95.6)$ & 0.429 \\
\hline Neurological diseases & $20(40)$ & $65(57.0)$ & 0.045 \\
\hline Hipertention & $20(40)$ & $49(42.9)$ & 0.721 \\
\hline Cardiovascular diseases & $14(28)$ & $31(27.2)$ & 0.915 \\
\hline Pulmonary diseases & $12(24)$ & $26(22.8)$ & 0.844 \\
\hline Diabetes mellitus & $14(28)$ & $23(20.1)$ & 0.275 \\
\hline Malignite & $13(26)$ & $16(14.0)$ & 0.720 \\
\hline Renal diseases & $11(22)$ & $15(13.1)$ & 0.168 \\
\hline Operation & $5(10)$ & $20(17.5)$ & 0.231 \\
\hline Trauma & $6(12)$ & $16(14.0)$ & 0.726 \\
\hline Development of infection in ICU, n (\%) & $27(54)$ & $38(33.3)$ & 0.013 \\
\hline Development of pneumonia in ICU & $20(40)$ & $23(20.2)$ & 0.008 \\
\hline Development of surgical site infection in ICU & $5(10)$ & $2(1.7)$ & 0.016 \\
\hline Development of catheter infection in ICU & $9(18)$ & $11(9.6)$ & 0.108 \\
\hline Development of urinary infection in ICU & $11(22)$ & $16(14.3)$ & 0.246 \\
\hline Mechanic ventilation, $\mathrm{n}(\%)$ & $50(100)$ & $38(33.3)$ & 0.000 \\
\hline Central venous catheter, n (\%) & $42(84)$ & $55(48.2)$ & 0.000 \\
\hline Nasogastric catheter, n (\%) & $46(92)$ & $57(50)$ & 0.000 \\
\hline Isolation of Acinetobacter spp., n (\%) & $10(20)$ & $5(4.4)$ & 0.001 \\
\hline Apache $\mathrm{II} \geq 15$ at admission, $\mathrm{n}(\%)$ & $40(80)$ & $48(42.1)$ & 0.000 \\
\hline
\end{tabular}

Table 4. Independent risk factors for mortality, the final model of ; odds ratios and confidence limits (Enter model)

\begin{tabular}{lcccc}
\hline & & & \multicolumn{2}{c}{$\mathbf{9 5 , 0 \%}$ Cl s } \\
& p-value & OR & Low & High \\
\hline Mechanic ventilation & 0.996 & 1.448 & 0.918 & 1.031 \\
Central venous catheter & 0.492 & 1.522 & 0.459 & 5.047 \\
Isolation of Acinetobacter spp. & $\mathbf{0 . 0 2 5}$ & $\mathbf{6 . 4 4 6}$ & 1.261 & 32.960 \\
Development of infection in ICU & 0.188 & 1.188 & 0.106 & 1.554 \\
Neurological disease & 0.101 & 0.442 & 0.166 & 1.173 \\
Surgical site infection & $\mathbf{0 . 0 4 0}$ & $\mathbf{1 3 . 7 8}$ & 1.122 & 169.157 \\
Pneumonia & 0.320 & 0.436 & 0.085 & 2.244 \\
APACHE II score $\geq 15$ at admission & $\mathbf{0 . 0 3 9}$ & $\mathbf{3 . 0 5 7}$ & 1.055 & 8.856 \\
\hline
\end{tabular}

\section{DISCUSSION}

Infections acquired during a stay in the ICU constitute a major part of NIs $[3,4,12)$. Patients admitted to the ICU are vulnerable to NIs due to significant risk factors such as reduced host defenses, invasive de- vices use, damage of anatomical barrier (intubation, mechanical ventilation, vascular access, etc.), and administration of several drugs that create a predisposition for infections (e.g., sedatives, muscle relaxants, stress ulcer prophylaxis) [3]. ICUs are one of the units that have the highest occurrence rates of 
infections [3,9]. The incidence of infection is two to five times higher in ICUs than in the general inpatient population [5].

The $\mathrm{NI}$ rates in the ICU were reported in a wide range of 9.6 and $48.7 \%$ in the previous studies [6,5,13-15], which includes the infection rate of $39.0 \%$ in the current study. In the Extended Prevalence of Infection in Intensive Care (EPIC) II study, conducted as a one-day point-prevalence study across Europe in 2007, infection rate was found to be $51 \%$, higher than the previous rate of $20.6 \%$ reported in the 1992 EPIC study $[9,16]$. The ICU infection rates may vary between centers, depending on the characteristics of patients and ICUs $[15,17]$. Furthermore, there are some personal practical differences in implementation of surveillance methods and diagnostic criteria. For this reason, comparison of $\mathrm{NI}$ rates from different ICUs is difficult.

Pneumonia is reported to be the most frequent infection in the ICU, followed by urinary tract infection $[4,12]$. Similarly, pneumonia was found to be the most frequent infection in the present study. This was similar to the results of the EPIC study, the EPIC II study, and the other studies $[9,13,14,16]$. Pneumonia rates may vary based on ICU level and the rates of connecting to mechanical ventilation.

NIs in the present study were most frequently caused by $A$. baumannii, similar to the majority of studies in which gram-negative organisms were the predominant agent $[13,15,16,18]$. Acinetobacter isolates were resistant to many antibiotics, including carbapenems. Due to the appearance of multidrug resistant pathogens, ICU infections have been considered a major threat for public health in recent years. Infection with multidrug resistant pathogens causes an increase in morbidity, mortality, and economic burden $[3,13,16]$. Frequent use of broad spectrum antibiotics causes ICU patients to become vulnerable to infections from multidrugresistant microorganisms [13].

The mortality rates in the ICU were reported in the range of $19.6 \%-60 \%[2,5,6,13,15,19-22)$, and several risk factors were described in the previous reports $[6,7,13,16,17,19]$. Underlying disease was found associated with mortality in many studies $[2,7,19,22]$. However, in the present study, underlying disease was not a significant risk factor for mortality. Older age was reported to be a risk factor for mortality in the majority of the studies $[2,5,6,16)$. However, in the present study, older age was not found to be a risk factor for mortality, which was compatible with the study reported by Cevik et al. [6].
Invasive procedures, especially mechanical ventilation, have been reported as risk factors for mortality in many studies $[5-7,9,16,19,22,23]$. In the current study, mechanical ventilation, central venous catheter, and nasogastric catheter were associated with mortality by univariate analysis $(P=0.001$ for each), but there was no association between mortality and invasive procedures in multivariate analysis.

The association between mortality and disease severity scores has been investigated in many studies [5-7,16,22,24-26]. A high APACHE II score was reported as an independent risk factor for mortality in the majority of previous studies $[5,7,22,25]$, while some studies did not find an association between APACHE II score and mortality [2,24]. In the current study, a high APACHE II score $(\geq 15)$ at the time of admission was found to be significantly associated with mortality, which was consistent with the study of Meric et al. [5].

Severe NIs and multidrug resistance (MDR) are associated with a poor prognosis for patients in intensive care units $[1,25]$. In the majority of studies, infections acquired in the ICU were found to be independently associated with an increased risk for mortality $[9,16,19,27,28]$, while other studies did not find any association between infections and mortality $[2,13,23]$. The EPIC study showed an association between mortality and ICU-acquired pneumonia, clinical sepsis, and bloodstream infections [9]. Similarly, in the study of Cevik et al., pneumonia acquired in the ICU was associated with increased mortality [6]. In the present study, infections occurred significantly more frequently in patients in the "died" group than in the "survived" group in univariate analysis $(p=0.013)$. However, multivariate analysis results indicated an association only between surgical site infections and mortality $(p=0.040)$.

The impact of increased length of ICU stay on nosocomial infections and mortality has been investigated in many studies [5,6,8,9,15,16,20,23,29]. In the majority of the studies, increased length of stay was found to be an independent risk factor for ICU-acquired infection $[5,15,16,20,23]$. Some studies showed that the length of stay was longer in infected patients than in uninfected cases [13). In this study, infection with $A$. baumannii caused an increase in the length of ICU stay, similar to the other studies $[29,30]$. Hospitalization in the ICU for longer than 21 days was found to be an independent factor associated with mortality in the EPIC study [9]. The other studies also showed an increase in mortality rate in cases of prolonged hospitalization $[8,20]$. In 
the present study, the length of ICU stay was not statistically different between patients in the "died" and "survived" groups, which was consistent with the study of Cevik et al. [6].

Due to its high level of resistance to many antibiotics, $A$. baumannii has become a pathogen that is difficult to treat [16]. The majority of studies showed that $A$. baumannii infection was an independent risk factor for mortality $[3,8]$, while a few studies investigating outcomes of infection in the ICU showed that $A$. baumannii infection was not associated with mortality $[24,29]$. In the present study, A. baumannii infection was found to be an independent risk factor for mortality $(p=0.025)$. A. baumannii has recently emerged as an important nosocomial pathogen and mainly affects patients with impaired host defenses in the ICU. Resistance to commonly used antibiotics, including cephalosporins, aminoglycosides, quinolones, and carbapenems is another concern relating to $A$. baumannii infection [3].

In conclusion, a high APACHE II score at admission, surgical site infection, and infections caused by $A$. baumannii increase the mortality rates in the ICU. In addition, infection caused by $A$. baumannii is associated with increased duration of ICU stay. The treatment of $A$. baumannii infections is difficult due to a higher resistance rate to commonly used antibiotics. In order to decrease the mortality rates, empirical treatment should cover $A$. baumannii isolates in endemic ICUs.

\section{Conflict of interest statement: None declared.}

\section{Acknowledgements}

We would like to thank all data collectors and the participants in this study. No fund was available for this study.

Declaration of Conflicting Interests: The authors declare that they have no conflict of interest.

Financial Disclosure: No financial support was received.

\section{REFERENCES}

1. Blot S. Limiting the attributable mortality of nosocomial infection and multidrug resistance in intensive care units. Clin Microbiol Infect 2008;14:5-13.

2. Katsaragakis S, Markogiannakis H, Samara E, et al. Predictors of mortality of Acinetobacte rbaumannii infections: A 2-year prospective study in a Greek surgical intensive care unit. Am J Infect Control 2010;38:631-635.

3. Brusselaers N, Vogelaers D, Blot S. The rising problem of antimicrobial resistance in the intensive care unit. Ann Intensive Care 2011;1:47.
4. Sardan YC. Hastane Enfeksiyonları, Tanımlar, Sürveyans ve Epidemilere Yaklaşım. Enfeksiyon Hastalıkları ve Mikrobiyolojisi. Topcu AW, Soyletir G, Doğanay M. 3rd edition. Ankara: Nobel Tıp Kitapevleri, 2008;545-557.(in Turkish)

5. Meric M, Willke A, Caglayan C, et al. Intensive care unitacquired infections: incidence, risk factors and associated mortality in a Turkish university hospital Jpn J Infect Dis 2005;58:297-302.

6. Çevik MA, Yılmaz GR, Erdinç FŞ, et al. Nöroloji yoğun bakım ünitesinde mortalite ile ilişkili faktörler ve nozokomiyal infeksiyonla mortalite ilişkisi. Yoğun Bakım Dergisi 2001;1:47-55. (in Turkısh)

7. Appelgren P, Hellström I, Weitzberg E, et al. Risk factors for nosocomial intensive care infection: a long-term prospective analysis. Acta Anaesthesiol Scand 2001;45:710-719.

8. Craven DE, Kunches LM, Lichtenberg DA, et al. Nosocomial and fatality in medical surgical intensive care unit patients. Arch Intern Med 1988;148:1161-1168.

9. Vincent JL, Bihari DJ, Suter PM, et al. The prevalence of nosocomial infection in intensive care units in Europe. Results of the European Prevalence of Infection in Intensive Care (EPIC) Study. EPIC International Advisory Committee. JAMA 1995;274:639-644.

10. Garner JS, Jarvis WR, Emori TG, et al: CDC definitions for nosocomial infections. Am J Infect Control 1988;16:128-140.

11. National Committee for Clinical Laboratory Standards. Antimicrobial susceptibility tests. Approved Standard M100-S19. Wayne, PA. NCCLS, 2009

12. Çağatay $A A$, Özsüt $H$. Yoğun bakım ünitesi infeksiyonları ve antimikrobik tedavi. Yoğun Bakım Dergisi 2001;1:21-32. (in Turkısh)

13. Pradhan NP, Bhat SM, Ghadage DP. Nosocomial infections in the medical ICU: a retrospective study highlighting their prevalence, microbiological profile and impact on ICU stay and mortality. J Assoc Physicians India 2014;62:18-21.

14. Esen S, Leblebicioglu H. Prevalence of nosocomial infections at Intensive care units in Turkey: a multicentre 1-day point prevalence study Scan J Infect Dis 2004;36:144-148.

15. Ak O, Batirel A, Ozer S, Colakoglu S. Nosocomial infections and risk factors in the intensive care unit of a teaching and research hospital: A prospective cohort study. Med Sci Monit 2011;17:29-34.

16. Vincent JL, Rello J, Marshall J, et al. International study of the prevalence and outcome of infection in intensive care units. JAMA 2009;302:2323-2329.

17. Yilmaz GR, Cevik MA, Erdinc FS, et al. The risk factors for infections acquired by cerebral hemorrhage and cerebral infarct patients in a neurology intensive care unit in Turkey. Jpn J Infect Dis2007;60:87-91.

18. Richards MJ, Edwards JR, Culver DH, et al. Nosocomial infections in medical intensive care units in the United States. National Nosocomial Infections Surveillance System. Crit Care Med 1999;27:887-892.

19. Ursavaş A, Ege E, Yüksel EG, et al. Solunumsal Yoğun Bakım Ünitesinde Mortaliteyi Etkileyen Faktörlerin Değerlendirilmesi. Yoğun Bakım Dergisi 2006;6:43-48. (In Turkısh)

20. Ceylan E, İtil O, Arı G et al. İç hastalıkları yoğun bakım ünitesinde izlenmiş hastalarda mortalite ve morbiditeyi etkileyen faktörler. Toraks Dergisi 2001;2:6-12.(in Turkısh)

21. Günal $H$, Çalışır HC, Erol $A$, et al. Solunumsal yoğun bakım ünitesindeki mortalite. Solunum Hastalıkları 2001;12:260267. 
22. Erbay $H$, Yalcin AN, Serin $S$, et al. Nosocomial infections in intensive care unit in a Turkish university hospital: a 2-year survey. Intensive Care Med 2003;29:1482-1488.

23. Ponce de LeónRosales SP, MolinarRamos F, DomínguezCherit G, et al. Prevalence of infections in intensive care units in Mexico: a multicenterstudy. Crit Care Med 2000;28:13161321.

24. Caricato A, Montini L, Bello G, et al. Risk factors and outcome of Acinetobacter baumanii infection in severe trauma patients. Intensive Care Med 2009;35:1964-1969.

25. Karabay O, Yahyaoğlu M, Öğütlü A, et al. Factors associated with mortality in Acinetobacter baumannii infected intensive care unit patients. Mikrobiyol Bul 2012;46:335-337.

26. Kim SY, Jung JY, Kang YA, et al.Risk factors for occurrence and 30-day mortality for carbapenem-resistant Acinetobacter baumannii bacteremia in an intensive care unit. $\mathrm{J}$ Korean Med Sci 2012; 27: 939-947.

27. Cevik MA, Yilmaz GR, Erdinc FS, et al. Relationship between nosocomial infection and mortality in a neurology intensive care unit in Turkey. J Hosp Infect 2005;59:324-330.

28. Vincent JL, Sakr Y, Sprung CL, et al. Sepsis in European intensive care units: results of the SOAP study. Crit Care Med 2006;34:344-353.

29. Jang TN, Lee $\mathrm{SH}$, Huang $\mathrm{CH}$, et al. Risk factors and impact of nosocomial Acinetobacter baumannii bloodstream infections in the adult intensive care unit: a case-control study. J Hosp Infect 2009;73:143-150.

30. García-Garmendia JL, Ortiz-Leyba C, Garnacho-Montero J, et al. Mortality and the increase in length of stay attributable to the acquisition of Acinetobacter in critically ill patients. Crit Care Med 1999;27:1794-1799. 